\title{
SPOŁECZNO-MORALNE PRZESŁANIE PEDAGOGICZNE KARDYNAŁA STEFANA WYSZYŃSKIEGO
}

\section{The Social-Moral Pedagogical Message of Cardinal Stefan Wyszyński}

S u m m a r y: Taking into account the specificity of the pedagogical message in the teaching of Cardinal Stefan Wyszyński in the field of social-moral upbringing, the author recalls the arguments confirming its objective and timeless value. Striving for a synthetic view of the actuality and attractiveness of the Primate's pedagogical thought, he draws attention to the following: What kind of man and teacher was Primate Stefan Wyszyński? How did he understand the essence of social-moral upbringing? Where are the roots of such an understanding of upbringing? What functions did he ascribe to it? Finally, what does he have to propose to contemporary theoreticians and practitioners of upbringing? The publication draws conclusions of a generalizable and applied nature.

Ke y w o r d s: Stefan cardinal Wyszyński, social-moral upbringing, its actuality

\section{Wprowadzenie}

Dysponując wieloaspektowymi analizami obszernego materiału badawczego, jakim jest pisarska i homiletyczna spuścizna Prymasa Tysiąclecia ${ }^{2}$, w niniejszej publikacji chcę jedynie przywołać kilka argumentów potwierdzających specyfikę

1 Alina Rynio - dr hab., pracownik Katedry Pedagogiki Chrześcijańskiej i Biografistyki Pedagogicznej w Instytucie Pedagogiki KUL JP II. Adres do korespondencji: Aleje Racławickie 14, 20-950 Lublin; e-mail: memor@kul.pl.

2 Por. Alina Rynio, Wychowanie młodzieży w nauczaniu Kardynała Stefana Wyszyńskiego (Lublin: Redakcja Wydawnictw KUL, 1995 i Lublin: Wydawnictwo KUL, 2001, wyd. 2); taż, „Mądre wychowanie patriotyczne przedmiotem troski Prymasa Tysiąclecia”. Studia Prymasowskie UKSW 4 (2011): 247-264; taż: „Cele wychowania 
i aktualność jego przesłania dotyczącego wychowania społeczno-moralnego. Dążąc do syntetycznego ujęcia tak sformułowanego tematu, wobec faktu, że dla młodszych pokoleń jest on postacią historyczną - przede wszystkim zwrócę uwagę na to, jakim człowiekiem i nauczycielem był ksiądz kardynał Stefan Wyszyński. Do czego sprowadzał rozumienie istoty wychowania społeczno-moralnego? Gdzie tkwi aktualność takiego sposobu pojmowania wychowania? Wreszcie, jaka jest uniwersalna wartość i znaczenie tak rozumianego wychowania?

Jakkolwiek ograniczone ramy publikacji nie pozwalają w sposób analityczny i wyczerpujący odpowiedzieć na tak sformułowane pytania, to jednak wydaje się, że wobec zauważanego dziś dość powszechnie kryzysu wychowania nawet połowiczna znajomość integralnej wizji wychowania dzieci i młodzieży kard. S. Wyszyńskiego nabiera szczególnej wagi i znaczenia. Cennym źródłem ukierunkowującym proces poznawania bogatego dziedzictwa Prymasa może być dwutomowa bibliografia Mariana Piotra Romaniuka Prymas Tysiąclecia w słowie pisanym, powstała w ramach realizacji Centralnego Projektu Badawczego IPN ${ }^{3}$, jak również cały szereg nowych, bardzo cennych opracowań, których nie sposób nie zauważyć4.

\section{Stefan Wyszyński jako człowiek, kapłan i nauczyciel}

Szukając odpowiedzi na pierwsze pytanie, warto podkreślić, że kardynał Stefan Wyszyński przede wszystkim był dobrym synem swoich rodziców, pilnym uczniem różnych szkół, w jakich pobierał naukę, harcmistrzem ZHP, klerykiem, a potem rektorem włocławskiego Seminarium Duchownego, studentem Katolickiego Uniwersytetu Lubelskiego, kapelanem Armii Krajowej i opiekunem ociemniałych dzieci. Był również biskupem lubelskim, Wielkim Kanclerzem KUL, a następnie prymasem i Ojcem Soboru Watykańskiego II. Określano go „dobrym pasterzem”, mężem stanu,

młodzieży w nauczaniu Prymasa Tysiąclecia. Analiza pedagogiczna w świetle Prawa i Przyrzeczenia Harcerskiego". W: Wychowanie chrześcijańskie metoda harcerską, red. Anna Petkowicz (Lublin: Wydawnictwo KUL 2009), 211-223; taż, „Myśl pedagogiczna Stefana Kardynała Wyszyńskiego”. W: Stefan Kardynał Wyszyński (1901-1981). Myśl społeczna, red. Stanisław Fel, Marek Wódka (Lublin: Wydawnictwo KUL, 2017), 47-70; taż, „Rodzina jako Kościół domowy w nauczaniu Kard. Stefana Wyszyńskiego”. W: Rodzina jako Kościół domowy, red. Antoni Tomkiewicz, Włodzimierz Wieczorek (Lublin: Wydawnictwo KUL, 2010), 115-131; taż: „Społeczne wychowanie młodzieży w nauczaniu Prymasa Tysiąclecia jako warunek przetrwania narodu i kultury”. W: O społeczeństwie, wychowaniu i pracy w myśli Kardynała Stefana Wyszyńskiego, red. Lidia Marszałek, Adam Solak (Warszawa: WN UKSW, 2010), 79-100; taż: „Wychowanie młodzieży w posłudze duszpasterskiej Stefana Kardynała Wyszyńskiego". W: Społeczna potrzeba pamięci. Osoba i dzieło Kardynała Stefana Wyszyńskiego Prymasa Tysiąclecia, red. Alina Rynio, Magdalena Parzyszek (Lublin: TN KUL, 2017), 237-260 i inne.

${ }^{3}$ Marian P. Romaniuk, Prymas Tysiąclecia w stowie pisanym. Bibliografia życia, twórczości i posługi Kardynała Stefana Wyszyńskiego 1921-2017 (Warszawa: WN UKSW, 2018).

${ }_{4}^{4}$ Prymas Wyszyński a niepodległa. Naród - Patriotyzm - Państwo w nauczaniu Prymasa Tysiaclecia, red. Ewa K. Czaczkowska, R. Łatka (Warszawa: WN UKSW, 2019); Alina Rynio, Idea narodu i odpowiedzialności za naród w kazaniach milenijnych Czcigodnego Stugi Bożego Kardynała Stefana Wyszyńskiego (Lublin: Wydawnictwo KUL, 2020); Stefan Wyszyński, Chrześcijańska doktryna społeczna, red. Marek Wódka, Stanisław Fel (Lublin: Wydawnictwo KUL, 2020) i inne. 
Prymasem Tysiąclecia, ojcem narodu, strażnikiem wiary, prekursorem lubelskiej szkoły katolickiej nauki społecznej, „niekoronowanym królem Polski”, a nade wszystko obrońcą prawdy, wolności i sprawiedliwości. Nazywano go też „księciem Kościoła”, obrońcą rodziny, narodu i państwa, przywódcą narodu, obrońcą praw i godności człowieka, prekursorem Soboru Watykańskiego II, strażnikiem prawa i moralności, kimś, kto skutecznie bronił wolności słowa i opinii i niemal przez całe życie zabiegał o to, aby Polska była Polską, by w Polsce po polsku się czuło i myślało i żeby rodzima kultura oraz duch chrześcijańskiego narodu (wiara katolicka) rozwijały się swobodnie.

Wyszyński urodził się 3 sierpnia 1901 roku w Zuzeli nad Bugiem, gdy Polski nie było na mapie Europy. W roku 1910 jego ojciec przeniósł się na nowe miejsce organisty - do parafii Andrzejewo koło Ostrowi Mazowieckiej. To tu młody Stefan zaczyna uczęszczać najpierw do szkoły, a później pobierał naukę u korepetytora. Tu przeżyje śmierć matki odchodzącej z tego świata w 33 roku życia. Stefan ma wówczas zaledwie lat 9 . W następnym roku jego ojciec obarczony pięciorgiem małych dzieci, ożeni się po raz drugi z Eugenią Godlewską. Dom Wyszyńskich z żywą religijnością łączył miłość do ojczyzny. Gdy Stefan miał 10 lat, w domu swego ojca dostał do ręki zakazaną książkę ukazującą historię Polski pt. Dwadzieścia cztery obrazki. Uczucia patriotyczne po kryjomu kształtowały również szkoła i harcerstwo.

Po zdaniu egzaminu z zakresu szkoły podstawowej przyszły Prymas uczęszcza w latach 1912-1915 do Gimnazjum im. Wojciecha Górskiego w Warszawie. Tu po raz pierwszy styka się z atmosferą środowiska wielkomiejskiego oraz z dążeniami narodowymi zmierzającymi do odzyskania niepodległości. W 1915 roku, na skutek przesuwania się wojennego frontu rosyjsko-niemieckiego na wschód, wraca do Andrzejewa i przez następne dwa lata uczęszczać będzie do gimnazjum w Łomży, gdzie kończy IV i V klasę. Tu włącza się czynnie w harcerstwo, co nie pozostało bez wpływu na kształt jego osobowości. Ostatnie lata gimnazjum na własną prośbę spędził w Liceum im. Piusa X we Włocławku. Studia w Wyższym Seminarium Duchownym, które rozpoczął w 1920 roku, trwały cztery lata. Koledzy przyszłego Prymasa otrzymali święcenia kapłańskie 29 czerwca 1924 roku.

Diakon Stefan został wyświęcony później, 3 sierpnia tegoż roku, gdyż choroba płuc zmusiła go do wyjazdu do szpitala na leczenie. Zaraz po Mszy prymicyjnej, którą odprawił przed cudownym obrazem Matki Bożej w dniu 5 sierpnia, Wyszyński musiał udać się na dalszą kurację i dopiero w październiku 1924 roku podjął obowiązki kapłańskie ${ }^{5}$.

W tym miejscu warto postawić pytanie: co kształtowało osobowość przyszłego prymasa w okresie jego dzieciństwa i wczesnej młodości? Niewątpliwie zasadniczy wpływ miała głęboka religijność państwa Wyszyńskich i całkowite poświęcenie się

${ }^{5}$ Władysław Miziołek, „Osobowość, życie i działalność Stefana Kardynała Wyszyńskiego Prymasa Polski”. W: Stuga Boży Stefan kardynat Wyszyński (1901-1981). Co Kościót i Polska zawdzięczaja Prymasowi Tysiaclecia?, red. Stefan Budzyński, Irena Burchacka, Adam Mazurek (Warszawa: Oficyna Wydawniczo-Poligraficzna „Adam”, 2000), 16. 
ze strony jego ojca służbie Kościoła w Andrzejewie. Ojciec występował również w obronie wiary katolickiej prześladowanej przez carat, zwłaszcza wśród unitów. Wątki te szczegółowo opisują zarówno A. Micewski ${ }^{6}$, M.P. Romaniuk ${ }^{7}$, P. Raina ${ }^{8}$, jak i E.K. Czaczkowska?.

W październiku 1924 roku ksiądz Stefan Wyszyński podejmuje pracę kapłańską na stanowisku wikariusza przy katedrze włocławskiej. Jednocześnie zostaje redaktorem dziennika diecezjalnego "Słowo Kujawskie” oraz pełni funkcję prefekta w szkółce fabrycznej „Celulozy”. Po roku pracy biskup włocławski wysyła młodego Wyszyńskiego na dalsze studia na Katolicki Uniwersytet Lubelski, na Wydział Prawa i Nauk Społeczno-Ekonomicznych. Pod kierunkiem księdza profesora Antoniego Szymańskiego ksiądz Wyszyński studiuje katolicką naukę społeczną i ekonomię. W czerwcu 1929 roku na podstawie pracy pt. Prawa rodziny, Kościoła i państwa do szkoły otrzymuje doktorat. Podczas studiów udziela się społecznie w Stowarzyszeniu Katolickiej Młodzieży Akademickiej „Odrodzenie” oraz w „Bratniaku”. W Lublinie duży wpływ na przyszłego prymasa Polski ma ksiądz Władysław Korniłowicz, dyrektor konwiktu dla księży studiujących na Katolickim Uniwersytecie Lubelskim. Między tymi dwoma kapłanami zawiązała się głęboka przyjaźń, trwająca do końca życia. Wyszyński darzy swego duchowego kierownika ogromnym szacunkiem, a w ostatnich latach swojego życia podjął się prowadzenia jego procesu beatyfikacyjnego ${ }^{10}$.

Jesienią 1929 roku ks. Wyszyński wyjeżdża za granicę. W celu pogłębienia swoich studiów i zapoznania się ze stanem katolickiej nauki społecznej oraz działalności społecznej odwiedza Austrię, Włochy, Francję, Belgię, Holandię i Niemcy. Po powrocie do kraju krótko pracuje jako wikariusz w Przedczu Kujawskim, szybko jednak wraca do Włocławka na stanowisko wikariusza przy katedrze, a także pełni szereg innych obowiązków: wykłada ekonomię społeczną i socjologię w seminarium duchownym, w roku 1932 zostaje naczelnym redaktorem „Ateneum Kapłańskiego” oraz pełni funkcję promotora sprawiedliwości i obrońcy węzła małżeńskiego. Od 1938 roku jest sędzią w Sądzie Biskupim. Jednakże jego zainteresowania społeczne sprawiają, że prowadzi Chrześcijański Uniwersytet Robotniczy, działa w Chrześcijańskich Związkach Zawodowych, organizuje Katolicki Związek Młodzieży Robotniczej, jednocześnie przez jakiś czas kieruje Sodalicją Mariańską Ziemian Ziemi Kujawsko-Dobrzyńskiej ${ }^{11}$.

W swojej działalności w związkach zawodowych zajmuje się oświatą robotniczą. Chodzi mu przede wszystkim o człowieka, jego godność i rozwój duchowy. W kazaniach na tematy społeczne podejmuje kwestie pracy i godziwej za nią zapłaty, mówi o prawach i obowiązkach. Jest zwolennikiem reform, ale nie na drodze rewolucji,

${ }^{6}$ Kardynał Wyszyński, prymas i mąż stanu (Paryż: Éditions du dialogue, 1982).

${ }^{7}$ Życie, twórczość i posługa Stefana Kardynała Wyszyńskiego Prymasa Tysiąclecia, t. 1 (Warszawa: Instytut Wydawniczy PAX, 1994).

${ }^{8}$ Stefan kardynał Wyszyński Prymas Polski, t. 1 (Londyn: Oficyna Poetów i Malarzy, 1979).

${ }^{9}$ Kardynał Wyszyński. Biografia (Kraków: Wydawnictwo Znak, 2013).

${ }^{10}$ Miziołek, „Osobowość”, 19.

11 Rynio, „Idea”, 23. 
lecz z punktu widzenia moralnego i duchowego dobra człowieka. Optuje za jego podniesieniem bez względu na to, czy człowiek ten żyje w mieście czy na wsi, czy jest młody czy stary, biedny czy ubogi. W swojej działalności edukacyjnej, obok takich terminów jak wychowanie, kształcenie, samokształcenie, samowychowanie człowieka w ciągu całego jego życia, koncentruje się nie tylko na istniejącym status quo i tym, co jest tu i teraz, ale zorientowany jest na to, co być może, co powinno zostać ulepszone, udoskonalone czy urzeczywistnione.

W okresie od listopada 1939 roku do wiosny 1945 ksiądz Wyszyński przebywa i działa na terenie tzw. Generalnej Guberni. Do lipca 1940 roku przebywa u ojca we Wrociszewie, następnie na prośbę księdza W. Korniłowicza i Sióstr Franciszkanek Służebnic Krzyża z Lasek obejmuje opiekę duchową nad grupą sióstr i niewidomych w majątku Zamoyskich w Kozłówce. Od listopada 1941 roku do czerwca 1942 pełni taką samą funkcję w pracy nad niewidomymi w Żułowie na ziemi lubelskiej. W czerwcu 1942 roku przenosi się do Lasek i pod konspiracyjnym pseudonimem „Siostra Cecylia” pełni obowiązki kapelana Zakładu dla Niewidomych.

We wszystkich miejscach, gdzie przebywa, nie ogranicza się do wypełniania przydzielonych mu obowiązków, ale gromadzi przy sobie inteligencję, wysiedleńców z terenów przyłączonych do Rzeszy, młodzież, robotników. Głosi konferencje religijne i społeczne, prowadzi dni skupienia. Podnosi na duchu cierpiących i prześladowanych, budzi ufność. W czasie Powstania Warszawskiego ksiądz Stefan Wyszyński zostaje kapelanem Armii Krajowej (pod pseudonimem „Radwan 2”) oraz kapelanem szpitala powstańczego w Laskach ${ }^{12}$. W lutym 1945 wraca do Włocławka i zajmuje się organizowaniem seminarium duchownego. Zostaje jego rektorem i proboszczem dwóch sąsiednich parafii - Kłobi i Zgłowiączki, a ponadto zostaje redaktorem tygodnika diecezjalnego „Ład Boży” i „Kroniki Diecezji Włocławskiej”. Pomimo ogromnej pracy, jaka była jego udziałem, w roku 1946 wydaje drukiem znaną później szeroko monografię pt. Duch pracy ludzkiej. 15 sierpnia 1945 ksiądz Stefan Wyszyński zostaje mianowany kanonikiem katedralnej kapituły włocławskiej, a 4 marca 1946 roku papież Pius XII mianuje go biskupem lubelskim, zaś w dwa lata później zostaje podniesiony do godności arcybiskupa gnieźnieńskiego i warszawskiego. Konsekracja biskupia odbyła się 12 maja 1946 roku na Jasnej Górze ${ }^{13}$. Dokonał jej kardynał August Hlond, ówczesny Prymas Polski. Czas posługi biskupiej w Lublinie ${ }^{14}$ jest okresem niezwykle intensywnym. Przez krótki czas swojej działalności duszpasterskiej prowadzonej w latach 1946-1948 daje się poznać jako człowiek wytrwałej i ogromnej pracy, wielkiej

${ }_{12}$ Por. Z. Zieliński, „Życie w służbie Boga i ojczyzny. Życiorys Księdza Prymasa Stefana Wyszyńskiego”. Chrześcijanin w Świecie 8/44 (1976): 20.

13 Tamże, 21.

14 Związki Prymasa z Lubelszczyzną opisuje wielu autorów. Jednak szczególne zasługi należy przyznać abp. Bolesławowi Pylakowi, autorowi publikacji Stefan Wyszyński Biskup Lubelski 1946-1949 (Lublin: RW KUL, 2000). Inną ciekawą inicjatywą wydawniczą dotyczącą tej kwestii jest przewodnik Śladami Księdza Stefana Wyszyńskiego, Lubelszczyzna - Zamojszczyzna - Ziemia Chetmska, red. A. Kulik (Lublin: Koło Przyjaciół Prymasa Tysiąclecia przy parafii pw. Św. Urszuli Ledóchowskiej w Lublinie, 2016). 
otwartości, bezpośredniości, odwagi, cierpliwości, wyrozumiałości, ufności, wymagający od siebie i od innych (szczególnie od swoich współpracowników), zarówno duchownych, jak i świeckich. Swoją posługę w Kościele lubelskim podejmuje w wyjątkowo trudnej sytuacji społecznej, politycznej i kościelnej. Przychodzi do diecezji, która wiele wycierpiała podczas dopiero co zakończonej wojny i wymagała ogromnego trudu, by odbudować jej struktury, jak i odnowy religijno-moralnej zamieszkujących jej tereny wiernych ${ }^{15}$. Biskup Stefan Wyszyński zdawał sobie sprawę, że w ideologicznej konfrontacji Kościoła z materialistyczną filozofią marksizmu konieczne jest umocnienie podstaw filozofii katolickiej wśród duchowieństwa, inteligencji i studiującej młodzieży. Dlatego jako Wielki Kanclerz Katolickiego Uniwersytetu Lubelskiego zaraz po objęciu tej funkcji podjął decyzję otwarcia Wydziału Filozofii Chrześcijańskiej, na którym już w listopadzie 1946 roku rozpoczęły się zajęcia. W tym samym roku reaktywuje, również przy KUL, Instytut Kultury Religijnej, na którym sam podejmuje wykłady z socjologii. Ponadto jako przewodniczący Komisji Episkopatu do spraw KUL przedstawia projekt wydania Encyklopedii Katolickiej, który Konferencja Episkopatu zatwierdziła i powierzyła jej redakcję profesorom $\mathrm{KUL}^{16}$. Posługę biskupią $\mathrm{w}$ diecezji lubelskiej bp S. Wyszyński rozpoczyna od odnowy duszpasterstwa. Wizytuje parafie, gromadzi kapłanów na różne duszpasterskie spotkania i rekolekcje, wygłasza kazania i rekolekcje do robotników, inteligencji i młodzieży akademickiej. Z relacji bpa B. Pylaka wynika, że w ciągu 2 lat i 8 miesięcy zwizytował 80 z 244 parafii, tj. 1/3 diecezji. Spotykał się z setkami osób, bierzmował tysiące młodzieży i dorosłych. Wizytował głównie tereny zniszczone i biedne, Zamojszczyznę, parafie nadwiślańskie ${ }^{17}$. Z duszpasterstwem była związania sprawa odbudowy zniszczonych przez wojnę świątyń i budynków kościelnych. Odbudowy wymagała katedra, gmach seminaryjny i szereg świątyń na terenie rozległej diecezji.

\section{Koncepcja społeczno-moralnego wychowania osoby}

Lansowane przez Wyszyńskiego społeczno-moralne wychowanie oparte jest na chrześcijańskiej koncepcji osoby, świata ${ }^{18}$ i moralności, uwzględnia istnienie odwiecznego ładu społecznego i moralnego ${ }^{19}$, uznaje podstawowe prawa człowieka,

15 Piotr Nitecki, „Z Włocławka do Lublina. Nominacja, konsekracja oraz ingres biskupa Stefana Wyszyńskiego”. Studia Włocławskie 11 (2009): 412-413.

16 Miziołek, „Osobowość, 22.

17 Por. Dzieci moje. Biskup Stefan Wyszyński Ordynariusz Lubelski 1946-1949. Pamiętnik wystawy zorganizowanej przez Fundację na rzecz Rodziny Nasza Tradycja, w 70. rocznice ingresu do Katedry Lubelskiej Biskupa Stefana Wyszyńskiego, red. Piotr K. Kuty (Lublin: Nasza Tradycja, 2017), 122, 128.

18 Por. Stefan Wyszyński, „O chrześcijańską wizję życia”. W: tegoż, Prymat człowieka w ładzie społecznym (Londyn: Odnowa, 1976), 139-148.

${ }_{19}$ Por. Stefan Wyszyński, O moralną odnowę Narodu. Do wiernych w bazylice gnieźnieńskiej 2.II.1981. NS, 1005-1011; tenże, „Oddajcie co Bożego, Bogu. Komentarz do Jasnogórskich Ślubów Narodu”. W: W światłach Tysiąclecia (Kraków: Wydawnictwo Znak, 1981), 115-121. 
jego godność, wolność, suwerenność ${ }^{20}$. Opiera się na rozumie umożliwiającym poznanie prawdy, na sumieniu moralnym zdolnym odróżniać dobro od zła, na nowej moralności, która jest miłością, dobru osoby w wymiarze indywidualnym i wspólnotowym, powinności moralnej, rozumności, odpowiedzialności społecznej, fascynacji pięknem i osobistej decyzji. Uznaje prymat osoby ludzkiej w życiu społecznym, jej prawa oraz obowiązki i traktuje osobę jako persona socialis. Dlatego też człowiek ma ukierunkowanie moralne i społeczne, „może żyć i rozwijać swoje właściwości tylko dzięki stosunkom z innymi ludźmi”21. Dokonuje się to i wyraża poprzez zakorzenienie i uczestnictwo osoby we wspólnocie rodzinnej, narodowej, wyznaniowej i religijnej. Udział w życiu tych społeczności i respektowanie fundamentalnych zasad ich funkcjonowania jest niezbędnym warunkiem życia i rozwoju osoby. Przekonanie o tym, iż człowiek realizuje się wśród ludzi, istnieje dla drugich, jest w tym nauczaniu wszechobecne. W izolacji od innych ludzi Wyszyński widział źródło egotyzmu, samolubstwa i najrozmaitszych psychicznych zniekształceń, zboczeń i zubożenia osobowości ludzkiej. W tworzeniu nowych form życia społecznego upatrywał przejaw ludzkiego życia i możliwość ubogacenia go. Źródło właściwości społecznych osoby lokalizował w samym człowieku, w jego naturze - odczytywanej przez etyczny, społeczny i teologiczny pryzmat, rozumie, woli, sercu, w cnotach, zaletach, talentach, ale także wadach i złych skłonnościach. „Człowiek zawsze jest istotą społeczną nie tylko w stosunku do tego, co posiada w kieszeni i w spichlerzu, ale i w stosunku do tego, co posiada w umyśle, woli i sercu"22. Uspołecznienie, w analizowanym nauczaniu, dotyczy zarówno właściwości duchowych, zasobów intelektualnych, cnót i wszystkiego, co jest w osobie jakimś dobrem, które jest człowiekowi dane, jak też i tego, co jest przez niego nabyte. Stąd też „należy pamiętać, że wszystkie wartości przez nas nabyte, nie tylko materialne, ale przede wszystkim duchowe muszą służyć innym"23. Każde działanie, nawet najbardziej osobiste, ma wymiar społeczny i moralny, a wszystko, co dzieje się w człowieku, wypełniając jego życie osobiste, równocześnie je przekracza. $\mathrm{W}$ myśl tego założenia nawet osobisty trud wgłębiania się w siebie podczas rozważań rekolekcyjnych nie jest trudem samolubnym, ale społecznym ${ }^{24}$.

Uznając za św. Tomaszem z Akwinu akt miłości za początek ludzkiej moralności, wskazuje na potrzebę obecności kogoś, kto zachwyci osobę wychowanka i zbierze wszystkie jego siły i je pobudzi, pociągając ku nieznanemu, a jednak pożądanemu i upragnionemu dobru, którym jest Tajemnica Boga, który jest miłością.

20 Stefan Wyszyński, Apel synodu w obronie praw człowieka. Po powrocie z Synodu Biskupów, Warszawa 26 I 1975 roku, NS, 619-627.

${ }^{21}$ Stefan Wyszyński, U podstaw soborowej nauki o człowieku. W nurcie zagadnień soborowych, red. Bohdan Bejze (Warszawa: Wydawnictwo Sióstr Loretanek, 1968), 135.

${ }_{22}$ Stefan Wyszyński, Kazania i przemówienia autoryzowane, t. 22 (1966), 429.

23 Tamże, 430.

24 Stefan Wyszyński, Kazania i przemówienia autoryzowane, t. 31 (1968), 96. 
Przyznając rodzinie priorytetowe prawo do wychowaniu swojego potomstwa, uświadamia jej, iż podobnie jak osoba jest ona podmiotem życia społecznego. Ma swoje prawa i obowiązki, w tym prawo do integralnego wychowania, które obejmowałoby „wychowanie fizyczne i higieniczne, wychowanie umysłu, woli i uczuć, wychowanie społeczno-zawodowe, narodowo-obywatelskie i moralno-religijne"25. Podkreślając rolę rodziny w całym życiu każdego człowieka i w życiu świata, ukazuje ją jako strukturę nie wyizolowaną, ale mającą liczne i konieczne odniesienia. Wynikają one z niezdolności do zaspokojenia wszystkich potrzeb członków rodziny. Dlatego też Prymas ukazuje rodzinę jako podstawową komórkę, która potrzebuje i oczekuje pomocy od tych wszystkich struktur społecznych, które bądź to na płaszczyźnie naturalnej (naród i państwo), bądź też na płaszczyźnie nadprzyrodzonej (Kościół) decydują o realizacji życiowego powołania osoby ludzkiej ${ }^{26}$. W nauczaniu Prymasa wszystkie szersze struktury życia społecznego, aby móc istnieć i funkcjonować, muszą opierać się na rodzinie, która jest wprawdzie najmniejszą komórką społeczną, wykazuje jednak największą trwałość i tym samym przewyższa wszystkie inne formy życia społecznego. Także naród, będąc najwyższym naturalnym organizmem społecznym, istnieje przez rodzinę. Dlatego też rodzina jest dla narodu największą radością i łaską, a jej moc nie wyczerpuje się tylko w sile biologicznej, ale wyraża się także jako siła moralna, wychowawcza i obywatelska. Stąd może ona stać się właściwym miejscem tworzenia moralno-religijnego i społecznego profilu osoby ludzkiej i środowiskiem tworzenia się relacji międzyosobowych kształtujących więzi patriotyczne, obywatelskie i narodowe, ogólnospołeczne i religijne. Rodzina, lansując postawy służby, oddania i odpowiedzialności, sprawia, że „Naród zabezpiecza się bardziej w Rodzinie niż w granicach Państwa"27.

W rozumieniu Prymasa społeczno-moralne wychowanie pełniło funkcję ogniwa więzi społecznej i historycznej, będąc równocześnie czynnikiem rozwoju i postępu cywilizacyjnego wszystkich ludzi żyjących pod każdą szerokością geograficzną i w każdych warunkach. Ważną funkcją pełnioną przez wychowanie jest uspołecznienie. Wychowanie, zakładając wspólnotowy charakter natury osoby, winno działać na człowieka uspołeczniająco. Dzięki wychowaniu człowiek staje się tym, kim być powinien, to znaczy: osiąga swoje uspołecznienie, spełnia się w społeczności rodzinnej, narodowej i kościelnej. W rozumieniu S. Wyszyńskiego wychowanie ma wprowadzać w te kręgi społeczności, pozwalając każdemu na odnalezienie w nich właściwego miejsca dla siebie. Ma też odgrywać rolę czynnika kształtującego i organizującego właściwy sposób funkcjonowania każdej z tych społeczności. Aby tak być mogło, wychowanie musi spełniać podstawowy wymiar. Jest to wymiar służby: z miłością i w miłości. Służebny charakter wychowania jest gwarancją pełnej realizacji osoby

25 Wyszyński, Oddajcie, 117.

${ }^{26}$ Por. Ryszard Ficek, Zaangażowanie chrześcijan w życie publiczne w kontekście nauczania kardynała Stefana Wyszyńskiego (Lublin: Wydawnictwo Archidiecezji Lubelskiej „Gaudium”, 2020), 96.

27 „Rodzina Bogiem silna”. W: Wielka Nowenna Tysiąclecia, 242. 
ludzkiej, zarówno w wymiarze indywidualnym, jak i wspólnotowym. Polega on na dostrzeżeniu i wypełnieniu właściwych celów i zadań młodzieży, rodziny, narodu i Kościoła w zakresie wychowania. Podejmując problem społeczno-moralnego wychowania dzieci i młodzieży, Wyszyński wkracza w realia życia społecznego, nie wyłączając zasad etycznych i praktyk funkcjonowania systemu społeczno-politycznego. Jego wychowanie jest nie tylko wychowaniem religijno-moralnym, mającym na celu uformowanie prawych sumień wychowywanych i wychowujących, ale wychowaniem uspołeczniającym, zatroskanym o wartości prospołeczne, moralne, duchowe i obyczajowe narodu ${ }^{28}$.

Wyrażona przez papieża Jana Pawła II prawda o tym, iż wychowanie ma zasadnicze znaczenie dla kształtowania stosunków międzyludzkich i społecznych, nieobcą była Wyszyńskiemu, który na każdym etapie swojej posługi nie przestawał zabiegać o to, aby wiara, przenikając życie we wszystkich jego wymiarach, stawała się kulturą, a człowiek szanując prawa dane przez Stwórcę każdemu stworzeniu budował świat w jedności i braterstwie i zasłużył na miano Syna Bożego, realizującego swoją pełnię we wspólnocie dzieci Bożych i jedności z całym stworzeniem. Ostatecznie kardynałowi Wyszyńskiemu chodziło o to, aby zgodnie z dewizą św. Augustyna „Bóg był uwielbiony, człowiek uszanowany, a ziemia obsłużona”. Tak formułowane zasady wychowawcze, którymi człowiek winien się kierować w życiu religijnym, moralnym, rodzinnym i społecznym, zmierzały do zrodzenia w wychowywanych nowej świadomości samych siebie. Jej treścią miało być całkowite, świadome i upragnione przylgnięcie do uprzedzającego człowieka Bożego planu i przeżywania czasu, przestrzeni i relacji międzyludzkich ze świadomością tej przynależności. W istocie prymasowskie rozumienie wychowania, uwzględniając całość wchodzących w nie czynników i przygotowując do otwarcia się ku całości wchodzących w grę elementów koniecznych do adekwatnej interpretacji własnego istnienia i istnienia świata, miało pomagać w urzeczywistnieniu pełnego człowieczeństwa wychowywanych i wychowujących. Nic więc dziwnego, iż tak rozumiane wychowanie w zakresie wartości, ideałów, norm i zasad, a także metod i środków, stanowi wartość ponadczasową godną nie tylko poznania, upowszechniania, ale i wykorzystania. Należy jednak pamiętać, iż sposób jego realizacji, zależny od warunków i czasów, w jakich proces wychowania przebiega, może być bardzo różny. Wynika to z faktu, iż cel prymasowskiego wychowania (wychowanie człowieka, obywatela i świętego) odpowiadając potrzebom człowieka ochrzczonego i uczestnika konkretnej społeczności, ściśle związany był z sytuacją indywidualną, społeczną, historyczną i narodową. Pamiętać też należy, że wypowiedzi Prymasa odnośnie do wychowania w każdym jego wymiarze powstały na bazie praktyki wychowawczej rozumianej w charakterze pewnej sztuki, którą należało posiąść. Nie przeszkadzało

28 Por. Stefan Wyszyński, „Idzie nowych ludzi plemię...” Wybór przemówień i rozważań (Pallotinum: Poznań - Warszawa, 1973); tenże, „Problem chrześcijańskiego wychowania młodzieży”, 21 VII 1968. Zeszyty Naukowe KUL 5/2 (1962), c3-12. 
to jednak Wyszyńskiemu w czynieniu z doświadczeń pedagogicznych przedmiotu rozważań filozoficzno-teologicznych i wskazywania kierunku reform ważnych dla praktyki wychowawczej w zakresie wychowania społeczno-moralnego. W rozważaniach tych dominują pytania o to, kim jest człowiek, jaka jest jego istota, jakie są jego zadania, ku czemu człowiek powinien ukierunkowywać swoje życie. Przedstawiając jasny obraz człowieczeństwa, Prymas uczył patrzeć na rzeczy doczesne w świetle ich sensu ostatecznego. W jego refleksji chodziło o wszechstronną analizę przedmiotu wychowania, jakim jest człowiek stający się dzięki wychowaniu samym sobą, a więc bytem prawdziwie wolnym i odpowiedzialnym w każdym wymiarze, nie wyłączając wymiaru społeczno-moralnego czy religijnego.

Prymas odpowiadając na szereg pytań rodziców i nauczycieli na temat wychowania, przybliżał jego istotę i zwracał uwagę na to, że proces ten przebiega zawsze w konkretnych okolicznościach czasu i przestrzeni. Dzieląc się wieloletnim i niebanalnym doświadczeniem pedagogicznym, z ogromną wnikliwością i wyczuciem opisuje tych, którzy wychowania czy też formacji potrzebują, jak również tych, którzy funkcje tę $\mathrm{z}$ odwagą i pełną świadomością podejmują. W jego bogatym przesłaniu pedagogicznym jest mowa o moralności, sumieniu, wolności, autorytecie, wzorach osobowych, rodzicach i nauczycielach, doświadczeniu, patriotyzmie, dziedzictwie ojców, potrzebie więzi z ojczyzną i narodem. Jest mowa o potrzebie uznania wartości ojczystych, tradycji, historii i twórczej kulturze. Prymas mówi też o przyjaźni, wierze, nadziei i miłości, literaturze pięknej, prawdzie, relacji wychowawczej, o najczęściej popełnianych przez dorosłych błędach wychowawczych, i o tym wszystkim, co one za sobą pociągają.

Widząc potrzebę wypracowywania właściwej koncepcji wychowania, doceniającej wszystko to, co składa się na ludzkie doświadczenie, jako wyzwanie pod adresem współczesnych sobie myślicieli i pedagogów stawiał zagrożone zarówno od strony teoretycznej, jak i praktycznej człowieczeństwo. Domagając się pełnego zrozumienia osoby ludzkiej zdolnej do samostanowienia i odpowiedzialnego uczestnictwa, ratując zagrożoną istotę człowieka, wskazywał na konsekwencje antypersonalistycznego i antyreligijnego myślenia o człowieku i jego relacjach interpersonalnych i wspólnotowych. Tym samym pokazywał, że teologiczno-pastoralny punkt widzenia problemu, jakim jest moralno-społeczne wychowanie dzieci i młodzieży, może też stawiać konkretne problemy dla psychologii pastoralnej, szczególnie tej, która pozostaje w nurcie psychologii egzystencjalno-humanistycznej i personalistycznej ${ }^{29}$.

Niewątpliwą zasługą Prymasa Tysiąclecia było praktyczne ukazanie motywacyjnej, modelowo-wzorczej i sprawczej funkcji religijności, stanowiącej podmiotowe ustosunkowanie się człowieka wobec Boga i religii katolickiej, rozumianej jako zespół prawd, norm i form zachowania wyjaśniających i regulujących stosunek zachodzący

${ }^{29}$ W sposób bardziej wyczerpujący pisałam o tym w swojej książce podoktorskiej pt. Wychowanie młodzieży w nauczaniu kardynała Stefana Wyszyńskiego opublikowanej staraniem Redakcji Wydawnictw Katolickiego Uniwersytetu Lubelskiego w 1995 roku, 275-306. 
między człowiekiem a Bogiem, jak również człowiekiem a człowiekiem i różnego rodzaju społecznościami w wychowaniu personalistycznym. Wyszyński ukazując religię jako wartość odpowiadającą istotnym potrzebom człowieka współczesnego, wychodząc od zainteresowań i potrzeb poznawczych właściwych dla okresu młodości i wiążąc religijność z całokształtem życia psychicznego, ukazywał religię jako coś bardzo pozytywnego i twórczego. W konsekwencji w proponowanym modelu wychowania Prymasowi chodziło o to, jak zaznaczył to w roku 1980 Jan Paweł II, przemawiając w siedzibie UNESCO w Paryżu, ażeby człowiek stawał się coraz bardziej człowiekiem, ażeby bardziej „był”, nie tylko więcej „miał” - aby poprzez wszystko, co „ma” i co „posiada”, umiał bardziej i pełniej być człowiekiem - to znaczy ażeby równocześnie umiał bardziej „być” nie tylko „, $\mathrm{z}$ drugimi”, ale i „dla drugich”30.

Ponadto Wyszyński odczytując komplementarnie treści historycznego przekazu nakazującego człowiekowi czynienie sobie ziemi poddaną, tę nadprzyrodzoną prawdę ukazywał w kategorii refleksji nad samotnością, podmiotowością i wspólnotowym dążeniem osoby ludzkiej. Odwołując się do początków dziejów człowieka, przypominał młodzieży prawdę, iż „sam Bóg pragnął, aby człowiek korzystał z pomocy innych ludzi" ${ }^{31}$. W niesieniu pomocy Prymas widział zasadniczą i prawidłową postawę człowieka. Uważał, że zawsze lepiej jest pomagać niż oczekiwać pomocy, lepiej dawać niż braćs ${ }^{32}$. Zachęcał do wypracowania w sobie zwyczaju pomagania człowiekowi w każdej potrzebie, najbardziej codziennej, zwykłej, ludzkiej. Pomoc innym miała się stać stałym stylem ludzi młodych. Pomagać należało najbliższym, sąsiadom i znajomym, a zwłaszcza chorym i ubogim. Tą postawą należało żyć wszędzie, w domu, szkole, zakładzie pracy, na ulicy, w tramwaju, sklepie i w Kościele ${ }^{33}$. W pragnieniu pomagania i służenia innym było miejsce na „społeczne miłowanie”, na którym winien być oparty ład moralny stanowiący kolejny element społeczno-moralnego wychowania młodych.

Temat ładu moralnego, podobnie jak wychowanie religijno-moralne, był w nauczaniu prymasowskim tematem kluczowym. Realizacja treści ładu moralnego uważana była za element warunkujący integralny rozwój osoby ludzkiej w jej społecznych relacjach, a zwłaszcza w odniesieniu do rodziny i narodu. W przestrzeganiu ładu widział Wyszyński wartość niezbędną do tworzenia własnej indywidualnej osobowości, a równocześnie zabezpieczenie bytu i uładzenie życia na ziemi. Wydaje się, że ład moralny był dla niego motywem, z którym należało uzgadniać zabieg pedagogizacji osoby w narodzie i narodu jako wspólnoty osób. Wychowanie w duchu respektowania ładu moralnego nie tylko miało pogłębić świadomość

30 Jan Paweł II, „Wychowanie jest pierwszym i zasadniczym zadaniem kultury”. Przemówienie w siedzibie Organizacji Narodów Zjednoczonych do spraw Oświaty, Nauki i Kultury [UNESCO], Paryż, 2 czerwca 1980. W: Wychowanie w nauczaniu Jana Pawła II (1978-1999) (Warszawa: Wyższa Szkoła Zarządzania i Przedsiębiorczości im. Bogdana Jańskiego, 2000), 130.

31 Stefan Wyszyński, Głos z Jasnej Góry (Warszawa: Akademia Teologii Katolickiej, 1986), 280.

32 Tamże.

33 Tamże, 283. 
własnej tożsamości, ale warunkowało także autentyczny postęp we wszystkich formach i sferach życia ludzkiego, nie wyłączając dziedziny społeczno-moralnej, politycznej, gospodarczej czy ekonomicznej ${ }^{34}$. Nie ulega też wątpliwości, że treść tego wychowania sprowadzała się do osiągnięcia ludzkiej dojrzałości ujawniającej się w sumieniu prawym, co stanowiło domenę wychowania moralnego. Ze swej istoty stanowiło ono długotrwały proces kształtowania charakteru, zaś uformowanie sumienia polegać miało na przyjęciu norm etycznych, dokonywaniu trafnych wyborów i ich realizowaniu ${ }^{35}$.

W nauce na temat sumienia ksiądz Wyszyński pozostaje na płaszczyźnie tradycyjnej doktryny chrześcijańskiej. Nie podaje też propozycji definicji sumienia. Odwołuje się do powszechnego, potocznego i intuicyjnego rozumienia, które dostrzega w nim normatywny osąd ludzkiego działania, zarówno własnego, jak i cudzego. Koncentrując się na formowaniu sumienia u konkretnego człowieka czy grupy osób, obok podstawowego i pryncypialnego sumienia osoby ludzkiej, mówi o sumieniu rodzinnym, narodowym, zawodowym czy sumieniu obywatelsko-politycznym ${ }^{36}$. Takie widzenie wymiarów sumienia wynika z konkretnej sytuacji osoby ludzkiej poddanej szczególnym wezwaniom Bożym w określonych relacjach społecznych.

\section{Aktualność prymasowskiej koncepcji wychowania ${ }^{37}$}

Mając na uwadze atrakcyjność prymasowskiej wizji wychowania jako takiego, a wychowania społeczno-moralnego w szczególności, należy ją widzieć na płaszczyźnie preferowanych przez niego celów, zasad, form i metod wychowawczych wynikających z określonej integralnej wizji osoby ludzkiej i wyzwań systemu totalitarnego (wojujący komunizm deprecjonował wartość życia ludzkiego, praw człowieka, rodziny, narodu i Kościoła), z jakimi przychodziło się mierzyć. Zasadą, na której opiera proces wychowania w dziedzinie moralno-społecznej, jest miłość Boga i człowieka. Propagowany proces wychowania zakładał współpracę między wychowującym i wychowywanym. Prymasowskie cele i metody można sprowadzić do informowania, formowania i inspirowania, zaś praktyka łączenia prawd teologicznych z filozoficznymi inspirowała do działania opartego na wolności, prawdzie i dobru. Jedną z dróg realizowania wychowania Kardynał Wyszyński upatrywał w uodpornieniu człowieka na nieprawdę, zło i brzydotę i nauczeniu

${ }^{34} \mathrm{O}$ tym piszę szerzej w artykule Społeczne wychowanie osoby w nauczaniu Prymasa Tysiąclecia (s. $222-225$ i n.).

35 Stefan Wyszyński, Listy Pasterskie Prymasa Polski (1958), 314.

36 Stefan Wyszyński, Sumienie prawe. U podstaw odnowy życia narodowego (Poznań - Warszawa: Pallotinum, 1981), 5-6.

37 Szerzej na ten temat piszę w: Alina Rynio, „Ponadczasowa wartość i atrakcyjność pedagogicznego przesłania czcigodnego Sługi Bożego kardynała Stefana Wyszyńskiego”. W: Rodzina - Wychowanie - Przyszłość, red. Elżbieta Osewska, Józef Stala (Kraków: WN UPJPII w Krakowie, 2020), 334-362. 
go rzetelnego odróżniania wartości od tego, co jest jej zaprzeczeniem. Ucząc samodzielnego myślenia i właściwego wartościowania, nie pozostawiał słuchaczy z wątpliwościami. Nazywając rzeczy po imieniu, nawiązywał do niezniszczalnych wartości ludzkich wiążących rozum, wolę i serce. W stosunkach ludzkich radził „zwyciężać siebie samego”, co oznaczało niejednokrotnie uznanie własnej kruchości, grzechu i potrzeby przebaczenia. Okazując niezwykłą wrażliwość na człowieka w każdym etapie jego życia, w wychowaniu nakazywał wprowadzać w przestrzeń tego, co piękne, dobre i prawdziwe. $\mathrm{W}$ tak rozumianym wychowaniu upatrywał znamię prawdziwego człowieczeństwa. Zalecał też przez umiejętne nakierowanie zainteresowań młodego człowieka tworzyć w nim nietolerancję dla zła i dokonywanie dobrych wyborów. Zabiegać o to trzeba było nie tyle na drodze karcenia, lecz zachęty, przychylności i ukazywania wzorów osobowych.

Analizowana pedagogia, będąca pedagogią wiary, nadziei i miłości, jakkolwiek nie jest ona w pełnym tego słowa znaczeniu dającą się opisać teorią naukową, stanowi nader ciekawy i istotny kierunek wychowania człowieka wierzącego realizującego swoje człowieczeństwo w okolicznościach nie zawsze sprzyjających. Wskazując na istotne dziedziny i obszary wychowania, Wyszyński przybliża wychowawcze aspekty kształtowania się własnej tożsamości wychowywanych i wychowujących. Stojąc na stanowisku realizmu pedagogicznego, uczył „badać wszystko i zachowywać jedynie to, co szlachetne”. Przybliżał też współczesne sobie dechrystianizujące i dehumanizujące konteksty, w jakich wychowanie się dokonywało.

Niewątpliwie Wyszyński, będąc człowiekiem prawym i roztropnym, a jeśli trzeba stanowczym, wpajał poczucie sprawiedliwości i prawdy. Jako wychowawca był jednostką mocną, harmonijną i kochającą, chciał być blisko tych, których nauczał, pragnął ich wzrostu, szanował ich wolność, widział ich w sposób realistyczny. Będąc człowiekiem niezachwianym w działaniu i w walce z przeciwnościami, miał świadomość własnego bogactwa wewnętrznego i pozytywnych wartości. Łączył w sobie mądrość działania, odpowiedzialność i służbę. W jego stylu życia widać, iż był uodporniony na cudze sądy, a równocześnie pozostał nieugodowy i nieprzejednany wobec zła. Nauczając, starał się pomagać osobom w autentycznym odkrywaniu własnych bogactw w zakresie intelektu, woli i uczucia ${ }^{38}$.

Od początku jego działalności duszpasterskiej i pisarskiej widoczny był wysiłek zmierzający do zrozumienia świata młodzieży. Jego kontakt zarówno z dziećmi, jak i młodzieżą był życzliwy, pełen akceptacji, szacunku i miłości, oparty na autorytecie moralnym i nastawiony na dawanie świadectwa prawdzie, którą się żyje bez względu na okoliczności. W tym miejscu nie boję się zaryzykować tezy, iż pedagogia Prymasa Tysiącleci jest pedagogią walki o dobro w sobie i wokół siebie przejawiającej się w pokonywaniu własnego egoizmu, opartej na służbie Bogu, bliźniemu i społeczności, w której się żyje. Rozumiejąc wychowanie jako współpracę z Bogiem

38 Szerzej piszę o tym w artykule „Wychowawcza wartość biografii Kardynała Stefana Wyszyńskiego”. Ateneum Kapłańskie 3 (2018): 469-486, jak również w: Wychowaniu do odpowiedzialności, 19-37. 
i człowiekiem w kolejnych fazach jego rozwoju, zwracał uwagę na praktyczną stronę wychowania. Wymagał uściślenia między teorią a praktyką, pomiędzy słowem a życiem. Podkreślał znaczenie współpracy na rzecz godności i szacunku oraz samego życia człowieka w wymiarze jednostki, jak też całego społeczeństwa. Jakkolwiek jego pedagogia ma charakter postulatywny, to jednak nie bał się podejmować tematów trudnych i niepopularnych wśród młodzieży i nauczycieli. W duchu nauki chrześcijańskiej przekładał na język zrozumiały dla współczesnych sobie pokoleń prawdę o tym, iż nadprzyrodzoność przenika rzeczywistość świata, a stawanie się nowym, dojrzałym duchowo człowiekiem dokonuje się przy wolnym udziale własnej aktywności współpracującej z łaską Bożą zawierającą w sobie łaskę przebaczenia. Wyszyński nie ukrywał, iż droga, którą należy pokonać, ażeby stać się autentycznie sobą samym, zakłada uznanie prawdy o uwikłaniu człowieka w grzech i domaga się przyjęcia oczyszczenia, poprzez które Bóg wyzwala człowieka ze wszystkiego, co zaciemnia autentyczne oblicze ludzkiego bytu. Uczył i uświadamiał, że droga ta domaga się od człowieka ufnego zawierzenia i oddania się Bogu. Z naciskiem też podkreślał, iż nie ma wychowania człowieka i ludzkości bez odnowy moralnej opartej na przebaczeniu, pokucie i osobistym nawróceniu, będącym odwróceniem się od tego wszystkiego, co zaciemnia Boży obraz w człowieku, czyniąc go bezwolnym i małodusznym. W rozumieniu Prymasa proces stawania się wolnym i odpowiedzialnym na drodze wychowania, uwzględniając konieczność adekwatnej interpretacji istnienia człowieka, moralności i świata, nie da się laboratoryjnie zbadać i przełożyć na język empirii. Rozumienie to może natomiast stanowić źródło inspiracji, wskazań i hipotez badawczych dla współczesnych psychologów, socjologów, teologów i pedagogów.

Szczególną atrakcyjność prymasowskiego przesłania pedagogicznego należy dostrzec także w tym, że nie zawęża on wychowania jedynie do oddziaływania samego tylko człowieka w różnym stopniu przygotowanego do tej funkcji, ale ukazuje wychowanie jako współdziałanie wychowanka i wychowawcy z łaską Bożą. Ponadto ukazuje, jak w procesie religijnego i moralno-społecznego formowania i dojrzewania człowieka można uniknąć dwutorowości polegającej na tym, iż jednym torem idzie myślenie i działanie religijne, innym zaś jego życie moralne, zawodowe czy społeczne. Prymas jest za ciągłą weryfikacją Bożych prawd i wymagań z rzeczywistością, w której człowiek żyje. W tym też wyraża swoje poczucie realizmu pedagogicznego, które wynikało z przeświadczenia zwerbalizowanego przez Johana Henry’ego Newmana, że „chrześcijaństwo ma swoje korzenie w chwalebnej przeszłości, ale jego siła jest teraźniejsza”.

Atrakcyjność prymasowskiej refleksji na temat społeczno-moralnego wychowania nade wszystko jednak tkwiła w jego postawie poznawczej wyrażającej się $\mathrm{w}$ realizmie, personalizmie i profetyzmie. Przejawem realizmu jest uwzględnienie realności rzeczywistości doczesnych, w tym również wychowania, i potraktowanie go jako przedmiotu refleksji antropologicznej, ontologicznej, etycznej i teologicznej. Wychowanie rozpatrywane zarówno ogólnie, jak i bardzo konkretnie, 
jednostkowo, w całym wymiarze egzystencjalnym zostało umieszczone przez Prymasa w kontekście realnych tajemnic Boga, Kościoła i wydarzeń zbawczych. Tak rozumiane wychowanie poprzez swój charakter dopełniający, służebny i zbawczy jest odzwierciedleniem działania stwórczego Boga, poprzez które osoba ma udział w kreacyjnym przeobrażaniu siebie i świata ${ }^{39}$.

W prymasowskiej wizji wychowanie pozostaje też w relacji z powołaniem ogólnoludzkim, a zarazem bardzo odrębnym i indywidualnym. Poprzez nie człowiek przygotowuje się do realizacji swojego życiowego powołania, które ma spełnić zgodnie z Bożym zamysłem. Wychowanie podejmowane $\mathrm{w}$ kategoriach powołania, mając wymiar doskonałościowy, staje się zadaniem, zasadą i szansą odnowy moralnej osoby odczytującej swoją wyjątkową wartośćc ${ }^{40}$.

Ponadto w omawianym nauczaniu aktualność wychowania może być widziana w fakcie jego służebnej funkcji dla określenia osobowości wychowywanego. Funkcja ta nie tylko określała osobowość, ale miała na celu doprowadzenie człowieka do zajęcia własnej, zarezerwowanej wyłącznie dla niego pozycji. Chodziło o to, aby w sposób odpowiedzialny człowiek mógł podjąć swoje życiowe zadanie. Takie ujęcie wychowania wynikało z jego służebnej roli wobec prawdy, a szczególnie prawdy o człowieku.

Nie bez znaczenia dla aktualności prymasowskiego przesłania pedagogicznego jest też jego interpretacja w duchu personalizmu chrześcijańskiego. W sposobie rozumienia przez kardynała Wyszyńskiego wychowania podkreślana jest specyfika wzrastania w człowieczeństwie ze świadomością tego, „kim się jest i kim być się powinno". W świadomości tak zorientowanej tkwi siła osoby, jej ideał i to, co do niego prowadzi. Równocześnie interpretacja ta zabezpiecza przed fałszywą apoteozą człowieka i jego możliwościami. Ambiwalentny charakter wychowania źródła wolności lub alienacji, szczęścia lub tragedii, prawdy lub fałszu - pozostaje w ścisłym związku z dramatem człowieka. Wydaje się, że to właśnie ukierunkowało myśl pedagogiczną Prymasa nie tyle do przeobrażeń systemowych, ile do odnowy człowieka, zakładając konieczne i niezbędne warunki istnienia ładu społeczno-moralnego. Odpowiednia jakość osobowości ludzkiej, całej społeczności, warunków społeczno-historycznych tworzą w sumie rzeczywistość, w której wychowanie jest nośnikiem takich elementów, jak doskonałość bytu, życie, szczęście, rozwój i wysoka wartość ludzkiej egzystencji ${ }^{41}$.

Niewątpliwie zasługą Prymasa jest również to, iż nie będąc teoretykiem wychowania i opierając swoje przesłanie na nauce Ewangelii i św. Tomasza z Akwinu przypomnianej przez o. J. Woronieckiego i J. Maritaina, upowszechniał podstawy integralnego systemu wychowawczego opartego na pełnym obrazie człowieka

\footnotetext{
${ }^{39}$ Por. Rynio, Wychowanie młodzieży w nauczaniu, 301.

40 Tamże.

${ }^{41}$ Por. Paweł Bortkiewicz, Promocja wartości pracy ludzkiej Kardynała Stefana Wyszyńskiego (Lublin: Praca doktorska, arch. KUL, 1989).
} 
wychowywanego. Co więcej - w swojej koncepcji wychowawczej szedł dalej niż neotomiści pomijający wartość kultury. W jego nauczaniu kultura osadzona jest na wartościach uniwersalnych, a każda osoba traktowana jest z godnością i szacunkiem jako autonomiczny podmiot zdolny do pomnażania dóbr kultury i tworzenia relacji $\mathrm{z}$ drugim człowiekiem i z Bogiem.

Wychodząc z założenia, że każde ludzkie dziecko potrzebuje wychowania i ma do niego prawo bez względu na kolor skóry, pochodzenie, stan materialny swoich rodziców czy ich wykształcenie, pragnął doskonalić całego człowieka. Doskonaląc jego tożsamość, odwoływał się do godności osoby, jej podmiotowości i pochodzenia człowieka od Boga. Podkreślając konieczność oddziaływania na całość osobowości wychowywanych, Wyszyński tak porządkował obraz świata, człowieka, celu i sensu jego istnienia, że harmonijny rozwój osoby ludzkiej stawał się nie tylko możliwy, ale także niepodważalny i oczywisty. Dokonywało się to na drodze ustawicznego budzenia wśród rodzin, dzieci i młodzieży, jak również wszelkich instytucji wychowujących poczucia ducha religijnego posłannictwa oraz głębokiej odpowiedzialności za religijno-moralne, a zarazem społeczne oblicze własnego życia i życia narodu. Wychodząc z chrześcijańskiej doktryny społecznej, nie tylko bronił prawdy, wolności i sprawiedliwości, ale mając ogromne zasługi dla katolickiej nauki społecznej, pozostawił nam wciąż aktualną personalistyczną koncepcję wychowania całego narodu. Przy czym naród jest dla Prymasa kategorią teologiczną i eklezjalną, a jego oryginalna chrześcijańska pedagogia narodowa oparta jest na wychowawczej funkcji dziejów i historii narodu, jak również potrzebie nowych świętych i błogosławionych ${ }^{42}$. Są nimi ci, którzy wierzą Bogu i ludziom, umieją miłować, są trzeźwi i wytrwali, zdolni do ofiar, poświęceń i trudów, a nadto są sumienni i obowiązkowi ${ }^{43}$.

\section{Uniwersalna wartość i znaczenie prymasowskiej myśli pedagogicznej}

Na szczególną uwagę zasługują te fragmenty myśli pedagogicznej Prymasa Wyszyńskiego, które sytuują wychowanie moralno-społeczne i religijne w uniwersalnym, ponadnarodowym procesie dziejów i rozwoju. Tak ujmowane wychowanie służyć miało tworzeniu więzi na wskroś uniwersalnej zarówno pod względem czasu, jak i przestrzeni. Uniwersalna i ponadczasowa wartość prymasowskich poglądów pedagogicznych jest widoczna w jego przesłaniach kierowanych do dzieci i młodzieży, rodziców, szkół, nauczycieli, duszpasterzy, zakonnic i zakonników czy sprawujących władzę w państwie polskim. Nie wchodząc w szczegóły, należy zauważyć, że Prymas dowartościowywał życie każdego człowieka, co wynikało

42 Zob. Rynio, Idea narodu, 55.

43 Por. Stefan Wyszyński, Kazania i przemówienia autoryzowane, t. 32 (Warszawa: 1969), 238-241. 
z prawa naturalnego, które implikowało prawa rodziny, narodu i Kościoła do wychowania. W zrozumieniu prawa naturalnego i jego związku z prawem stanowionym zwracał uwagę na potrzebę eliminowania fałszywej wizji człowieka opartej na błędzie antropologicznym pozbawiającym człowieka należnych mu praw, w tym prawa do życia, wychowania czy swobodnego wyrażania swoich poglądów. W obronie tych praw upatrywał podstawę ładu moralnego respektującego wartość i godność osoby, wolność, szacunek, dobro, sprawiedliwość społeczną, kierowanie się zasadą pomocniczości czy solidarności społecznej. Warto przy tym zauważyć, iż aspekt pewnego uniwersalizmu wychowania dzieci i młodzieży wyraża się nie tylko w nurcie społecznościowym, charakterystycznym dla Prymasa, ale znajduje swoje odzwierciedlenie także w jego refleksji teologicznej, która podkreśla charakter paschalny ludzkiego działania, nadając wychowaniu wartość zbawczą z uwzględnieniem nadrzędności innych, zwłaszcza sakramentalnych środków zbawienia. Twierdzenie, że praca wychowawcza ma w sobie coś ze „znaku świętego", ma pewne znamię sakramentalne i przynosi człowiekowi różnorodne dobra, łącznie z mocą zbawienia, jest niewątpliwie jedną z najbardziej oryginalnych refleksji teologicznych Wyszyńskiego. Usytuowanie wychowania w obszarze misterium paschalnego Chrystusa pozwala na odczytanie ambiwalencji zbawczej wychowania i jej kategorii paschalnej. Całą rzeczywistość ziemską, $w$ tym również obszar wychowania, przenika logika krzyża i zmartwychwstania Jezusa Chrystusa. Stąd też wychowanie, które nosi w sobie znamiona trudu i męki, włączone jest w realizm krzyża i nie staje się wyłącznie uciążliwością traktowaną w kategoriach przekleństwa, ale wpisane jest w optymizm zmartwychwstania. Kardynał Wyszyński wiążąc wychowanie z modlitwą i sakramentami, uważał, iż nie można go stawiać w opozycji do rzeczywistości nadprzyrodzonych, ale poprzez ofiarę i wyrzeczenie należy przygotowywać grunt dla Ewangelii, wprowadzając ją w obszar ludzkiej rzeczywistości młodych. Wychowanie odczytane przez pryzmat misterium paschalnego, podobnie jak praca, nabiera charakteru weryfikacji chrześcijańskiej prawdy o życiu, jego celu i sensie $\mathrm{w}$ znaczeniu ewangelicznym ${ }^{44}$. Umieszczenie rzeczywistości wychowania w optyce ewangelicznej sprawia, że terenem oddziaływań wychowawczych jest osobowe wnętrze człowieka otwartego ku eschatycznej przyszłości. Znamienne jest również to, że w myśli tej nie ma miejsca na izolacjonizm treści religijnych w stosunku do realiów konkretnej rzeczywistości. Jest wręcz przeciwnie. Jedynie realna i słuszna interpretacja wychowania osadzonego w konkretnym kontekście społecznym i historycznym jest możliwa w oparciu o przesłanie ewangeliczne ${ }^{45}$.

Ponadczasowe znaczenie i wartość prymasowskiego rozumienia wychowania ujawnia się także w tym, iż ma ono aspekt psychologiczno-moralny i społeczno-kulturowy. Widoczne jest to w ukazaniu wychowania jako zespołu działań i wysiłków człowieka zmierzających do jego dojrzałości i doskonałości psychosomatycznej,

\footnotetext{
${ }^{44}$ Tamże.

45 Tamże.
} 
zdobycia nowych wartości intelektualnych, estetycznych i moralnych oraz pełniejszego uczestnictwa człowieka w wartościach transcendentalnych. Personalizm Wyszyńskiego sprawia, że wychowanie zdaje się być mierzone wyjątkową godnością osoby ludzkiej. Wartość ta jest ukazywana jako nieustanne zadanie każdego wychowywanego i wychowującego. Z kolei wymiar społeczno-kulturowy wychowania odsłania możliwości tworzenia nowych wartości kulturowych, doskonalenia współżycia międzyludzkiego i współdziałania w kierunku odczytywania prawdy i tworzenia dobra ${ }^{46}$.

Ponadczasowa wartość tak rozumianego wychowania tkwi również w integralności podejścia i wrażliwości na wartość samego człowieczeństwa oraz na wszelkie wartości ducha ludzkiego. W nauczaniu Prymasa Tysiąclecia dotyczącym rzeczywistości, jaką jest wychowanie jako takie, a wychowanie społeczno-moralne w szczególności, z łatwością dostrzec można obecność doktryny Papieża Pawła VI „o pierwszeństwie osoby nad rzeczą, etyki nad techniką, bycia nad posiadaniem i miłosierdzia nad sprawiedliwością" ${ }^{47}$. Czwórmian ten, będąc swego rodzaju antidotum na zagrożenia zewnętrzne i wewnętrzne, stanowił formułę wychodzenia z licznych kryzysów towarzyszących człowiekowi czasów Wyszyńskiego. Wskazując na potrzebę pracy i aktywizowania własnych potencjalności, Prymas zakładał rozpoznanie przez człowieka istoty swego bytu i należnego mu miejsca w świecie. Korzystając z własnych życiowych doświadczeń i kładąc akcent na ludzkie działanie, uczył dobrego wykorzystania rozumu, woli i uczuć. Zakładana w warstwie celowościowej wychowania pełnia osoby, wyrażająca się w życiu opartym na odwiecznych wartościach prawdy, dobra i piękna, rozwijając sam podmiot wychowania, miała przechodzić na świat zewnętrzny, humanizując go $^{48}$ i czyniąc bardziej przyjaznym człowiekowi.

Mając na uwadze pedagogiczne przesłanie Prymasa Tysiąclecia widziane przez pryzmat zawartych w nim wartości, można powiedzieć, iż jego nauczanie o społeczno-moralnym wychowaniu człowieka, podobnie jak nauczanie o rodzinie, pracy, zaangażowaniu społecznym, narodzie, Kościele czy państwie, pełne jest uwagi dla problemu rozwoju, prawdy, miłości, twórczości, cierpienia i wiary. Wnosi istotny wkład w poznanie młodego człowieka w różnych wymiarach jego bytowania, nie zawsze możliwych do uwzględnienia przez nauki psychologiczno-pedagogiczne. Wyszyński pokazując złożoność i wagę diagnozy w pracy z rodziną, dziećmi i młodzieżą, uwrażliwia na potrzebę widzenia człowieka we wszystkich jego płaszczyznach i wymiarach. Stąd przemyślenia Prymasa pogłębiając spojrzenie na rodzinę, życie społeczne, naród, ojczyznę, państwo czy sam proces społeczno-moralnego wychowania człowieka, są ważne także i dziś, gdy pytania o przyszłość Polski i moralną kondycję młodego pokolenia ponownie nabierają istotnego znaczenia. Przedstawione wątki prymasowskiej koncepcji, szczególnie obecnie, wobec błędnego pojmowania celów i zadań wychowania, a także wobec ciągle groźnego

\footnotetext{
${ }^{46}$ Por. Wyszyński, Kazania i przemówienia autoryzowane, t. 32, 238-241.

${ }^{47}$ Rynio, Wychowanie młodzieży w nauczaniu, 303.

48 Wyszyński, Kazania i przemówienia autoryzowane, t. 32, 238-241.
} 
pragmatyzmu, liberalizmu, cyberprzemocy i wielu innych „izmów” na gruncie wychowania, mogą stanowić źródło inspiracji do nowych poszukiwań i przemyśleń, jak również pomoc w weryfikacji istniejących i tworzonych obecnie teorii.

Warto też podkreślić, że społeczno-moralnemu wychowaniu osobowemu przypisuje Prymas rolę decydującą nie tylko w dziedzinie humanizacji czy socjalizacji, ale także w dziedzinie relacji człowieka do Boga. Można więc powiedzieć, że w ideale wychowawczym Prymasa niejako idą w parze serce i sumienie, umysł i uczucia, nauka i religia, idealizm i realizm, filozofia i zdrowy rozsądek, wiara i rozum, to, co dawne, i to, co współczesne, autorytet i wolność. Powrót do źródeł ewangelicznych, świadomość daru wiary, dawanie świadectwa nadziei, służba na rzecz formowania sumienia prawego i tworzenia wspólnoty znajdują w tym nauczaniu pełne odzwierciedlenie. Równocześnie próbując udzielić odpowiedzi na pytanie, co czynić, aby praca z młodzieżą przynosiła oczekiwane owoce, Prymas nie daje jednoznacznych odpowiedzi. Zostawia ten problem otwartym, skłaniając wszystkich pracujących $\mathrm{z}$ młodzieżą do ciągłego poszukiwania przy jednoczesnym korzystaniu $\mathrm{z}$ dorobku innych. W poznaniu niebezpieczeństw zagrażających wychowaniu religijnemu i społeczno-moralnemu młodzieży dostrzega połowę sukcesu. Prymas postuluje oparcie wychowania młodzieży na zasadzie współdziałania instytucji wychowujących, podkreślając przy tym priorytetową rolę rodziny. Podejmując zaś wychowawcze powinności Kościoła, szczególnie po Soborze Watykańskim II, podkreśla służebny charakter Kościoła i pokazuje, co jest jego troską, obowiązkiem i jaką ma on rolę do spełnienia. Postuluje odnowę wychowania i dostosowanie go do warunków czasu i życia. Uwzględnia przy tym prawdę i doświadczenie życiowe.

To, co powiedziano powyżej, oznacza, że w analizowanych wypowiedziach, podobnie jak w encyklice O chrześcijańskim wychowaniu papieża Piusa XI, zawarty jest konkretny osąd proponowanych ujęć wychowania, które pozostawały w opozycji do nauczania Prymasa ${ }^{49}$.

Co więcej, Wyszyński czerpiąc z prawd objawionych zawartych w Piśmie świętym, dokumentach Urzędu Nauczycielskiego, dorobku uczonych katolickich i tradycji chrześcijańskiej, w swych wypowiedziach nie pozostawał tylko na poziomie oceny przynoszącej interpretację i wyjaśnienie błędnych ujęć misji i posłannictwa rodziny, narodu, państwa czy Kościoła, ale wskazywał środki zaradcze w formie konkretnych wskazań duszpasterskich. Szczególnie jest to widoczne w Kazaniach i przemówieniach z okresu Wielkiej Nowenny ${ }^{50}$, w Listach Pasterskich Prymasa Polski ${ }^{51}$ czy w Wykładach uniwersyteckich dla duchowieństwa ${ }^{52}$.

49 Por. Stefan Wyszyński, „Przewodnie myśli Encykliki o chrześcijańskim wychowaniu młodzieży”. Ateneum Kapłańskie 26 (1929): 1-22.

${ }^{50}$ Por. Stefan Wyszyński, Wielka Nowenna Tysiaclecia (Paryż: Éditions du dialogue, 1982), tenże, Uświęcenie pracy zawodowej (Paryż: Éditions du dialogue, 1963).

${ }_{51}$ Por. Listy Pasterskie Prymasa Polski 1946-1974 (Paryż: Wydawnictwo Paris, 1975).

${ }_{52}$ Por. Stefan Wyszyński, Problem chrześcijańskiego wychowania młodzieży. Przemówienie wygłoszone podczas wykładów uniwersyteckich dla duchowieństwa w dniu 21 VIII 1968 roku (tekst autoryzowany, 
Jego stanowisko odnośnie do wychowania we wszystkich jego aspektach nie było neutralne aksjologicznie czy aretologicznie. Korzeniami swymi sięgało jego przekonań filozoficzno-teologicznych. Dostrzegając problemy wynikające z polskiego doświadczenia społecznego, politycznego i pedagogicznego, zabarwionego filozofią marksistowską, Prymas ujawniał niepokój wobec płynących stąd zagrożeń zarówno dla człowieka, rodziny, narodu, wychowania, jak i całego społeczeństwa ${ }^{53}$. Przyjmował też stałą koncepcję ich wyjaśniania. Była ona oparta na koncepcji człowieka, jego relacji do innych i do Boga. W świetle tej ostatniej rozpatrywane były przyczyny niepowodzeń wychowawczych i ustalane środki zaradcze.

Wnikliwa refleksja wokół pedagogicznego przesłania kardynała Stefana Wyszyńskiego pozwala nam zgłębić prawdę wychowania moralno-społecznego, które jakkolwiek samo w sobie nie było i nie jest rzeczą łatwą, to jednak jest ludzką potrzebą, która jest realizowana, o ile szanuje naturę i kulturę, odbywa się w teraźniejszości, łącząc przeszłość i przyszłość, a nie deprecjonując tego, co tu i teraz, jest otwarte na to, co odwieczne, mądre, tradycyjne, piękne dobre i prawdziwe.

Jakkolwiek nie jest zasadne bezkrytyczne przejmowanie dawnych paradygmatów wychowawczych, to jednak pedagogiczne i społeczne dziedzictwo kardynała Stefana Wyszyńskiego jest godne ustawicznego poznawania i refleksji naukowej, ponieważ niesie bardzo ważne przesłania dotyczące godności osoby, wartości rodziny, prawego sumienia, poszanowania praw ludzkich, umiłowania ojczyzny oraz dziedzictwa kultury, prawdy, wiary, miłości i nadziei. Przesłań tych nie możemy lekceważyć, szczególnie dziś, gdy w przestrzeni społecznej do głosu dochodzi gwałtowny egoistyczny indywidualizm, hedonizm i relatywizm moralny, a wielu młodych i dorosłych przeżywa kryzys tożsamości pociągający za sobą kryzys rodziny i kryzys wychowania. W tych okolicznościach znajomość wyjątkowo cennego pedagogicznego dziedzictwa Prymasa Tysiąclecia daje klucz do podejmowania współczesnych zadań wychowawczych i społecznych, ponieważ opiera się na ponadczasowych założeniach dotyczących człowieka, rodziny, wspólnoty narodowej, państwa, tradycji i historii. Rozumienie, kim jest człowiek i jaki jest cel jego życia, a także jak przebiega proces jego rozwoju i wychowania, pozwala jasno stawiać cele każdemu działaniu wychowawczemu, zaś wychowawca, który wie, do czego wychowuje, zyskuje świadomość potrzebnych mu umiejętności wychowawczych, przyjmowanych zasad, metod i konkretnych działań. Jednak bez samowychowawczej i permanentnej pracy nad sobą nie pojawi się „nowych ludzi plemię”, a dialog można prowadzić z każdym, ale trzeba umieć zachować własną tożsamość.

Na koniec warto zauważyć, że Prymas Tysiąclecia, będąc krytycznym zarówno wobec liberalizmu, jak i kolektywizmu, wskazywał na trzecią drogę opartą na katolickiej nauce społecznej, afirmującej prymat godności człowieka, dobra

Zeszyty Naukowe KUL 12 (1969) nr 2, 3-15; tenże, Do rodziców w sprawie religijnego wychowania dzieci i młodzieży, Gniezno, 15 VIII 1951 roku, LPPP, 207-211.

${ }^{53}$ Por. R. Kadziński, „Wskazania Prymasa Tysiąclecia dla „Solidarności«”. Słowo Powszechne 147 (1986). 
wspólnego, solidarności społecznej i pomocniczości. Z jego przesłania wynika też, że aby odważnie patrzeć w przyszłość, potrzeba nam nie tylko dobrej znajomości przysługujących praw, ale „potrzebujemy prawdy zaślubionej w miłości, potrzebujemy stosownej wiedzy, znajomości dziedzictwa kulturowego, systematycznej pracy, rozwijania talentów, cierpliwości do siebie i do innych, skupienia i ciszy”. Jest to o tyle istotne, że „współczesna polska szkoła absolutyzuje prawa ucznia, a jednocześnie lekceważy egzekwowanie od niego obowiązków oraz odpowiedzialności za siebie i owoce swojej pracy" ${ }^{\prime 5}$. Warto też pokazywać młodzieży, jak kardynał Stefan Wyszyński rozumiał nie tylko wychowanie, sumienie, ale i patriotyzm, który wyraźnie odróżniał od nacjonalizmu i kosmopolityzmu. Nie można też pominąć fundamentalnej kwestii, jaką jest idea narodu i odpowiedzialności za naród, wolności i tolerancji, jego spojrzenia na wartość małżeństwa i rodziny, męskość i kobiecość, ojcostwo i macierzyństwo, życie nienarodzonych, potrzebę permanentnej formacji, samowychowania i zrównoważonego rozwoju, ekologię, niepełnosprawność i cierpienie, jak również jego spojrzenia na pracę, wolny rynek, demokrację, rolę przynależności do harcerstwa, KSM-u, Odrodzenia, Caritasu czy katolicką naukę społeczną.

St res z c z e n i e: Autorka publikacji, mając na uwadze specyfikę przesłania pedagogicznego w nauczaniu kardynała Stefana Wyszyńskiego w zakresie wychowania społeczno-moralnego, przywołuje argumenty potwierdzające jego obiektywną i ponadczasową wartość. Dążąc do syntetycznego spojrzenia na aktualność i atrakcyjność prymasowskiej myśli pedagogicznej, zwraca uwagę na to, jakim człowiekiem i nauczycielem był Prymas Stefan Wyszyński, jak rozumiał istotę wychowania społeczno-moralnego, gdzie tkwi geneza takiego sposobu rozumienia wychowania oraz w czym jest ono atrakcyjne. Wreszcie, jaka jest wartość tak rozumianego wychowania i jakie wnioski o charakterze uogólniającym i aplikacyjnym stąd wynikają.

Sło w a kl u c z o w e: Stefan kardynał Wyszyński, wychowanie społeczno-moralne, aktualność pedagogii Prymasa Wyszyńskiego

\section{Bibliografia}

\section{Źródła archiwalne}

Archiwum Instytutu Prymasowskiego

Wyszyński, Stefan. Kazania i przemówienia autoryzowane, t. 1-67 mps. Warszawa 1956-1981 (AIP).

\section{Źródła drukowane}

Wyszyński, Stefan. Apel synodu w obronie praw człowieka. Po powrocie z Synodu Biskupów. Warszawa 26 I 1975 roku, NS., 619-627.

Wyszyński, Stefan. Do rodziców w sprawie religijnego wychowania dzieci i młodzieży. Gniezno, 15 VIII 1951, LPPP, 207-211.

\footnotetext{
${ }^{54}$ Bogdan Kędziora, „Zawalczmy o młode pokolenie”. Niedziela 5/31 (2021): 49.
} 
Wyszyński, Stefan. Głos z Jasnej Góry. Warszawa: Akademia Teologii Katolickiej, 1986.

Wyszyński, Stefan. „Idzie nowych ludzi plemię...” Wybór przemówień i rozważań. Pallotinum: Poznań

- Warszawa, 1973.

Wyszyński, Stefan. Listy Pasterskie Prymasa Polski 1946-1974. Paryż: Wydawnictwo Paris, 1975.

Wyszyński, Stefan. Najważniejsza wartościa na świecie jest człowiek. Do delegacji NSZZ „Solidarność”

Regionu Mazowsze, 19 X 1980, NS. Warszawa: 1990, 960-965.

Wyszyński, Stefan. „O chrześcijańską wizję życia”. W: Prymat człowieka w ładzie społecznym, 139-148.

Londyn: Odnowa, 1976.

Wyszyński Stefan. O moralnq̨ odnowę Narodu. Do wiernych w bazylice gnieźnieńskiej 2 II 1981 roku, NS, 1005-1011.

Wyszyński, Stefan. „Oddajcie co Bożego, Bogu. Komentarz do Jasnogórskich Ślubów Narodu”.

W: W światłach Tysiąclecia, 115-121. Kraków: Wydawnictwo Znak, 1981.

Wyszyński, Stefan. „Problem chrześcijańskiego wychowania młodzieży, 21 VII 1968”. Zeszyty Naukowe KUL 5/2 (1962): 3-12.

Wyszyński, Stefan. „Problem chrześcijańskiego wychowania młodzieży”. Przemówienie wygłoszone

podczas Wykładów uniwersyteckich dla duchowieństwa w dniu 21 VIII 1968 roku (tekst autoryzowany). Zeszyty Naukowe KUL 12 (1969): 3-15.

Wyszyński, Stefan. „Przewodnie myśli Encykliki o chrześcijańskim wychowaniu młodzieży”. Ateneum

Kapłańskie 26 (1929): 1-22.

Wyszyński, Stefan. Sumienie prawe u podstaw odnowy życia narodowego. Do wiernych w archikatedrze warszawskiej, 6 I 1981 roku, NS, 986-994.

Wyszyński, Stefan. Wielka Nowenna Tysiąclecia. Paryż: Éditions du dialogue, 1982.

Wyszyński, Stefan. „U podstaw soborowej nauki o człowieku”. W: W nurcie zagadnień soborowych,

red. Bohdan Bejze, 129-156. Warszawa: Wydawnictwo Sióstr Loretanek, 1968.

Wyszyński, Stefan. Uświęcenie pracy zawodowej. Paryż: Éditions du dialogue, 1963.

\section{Opracowania}

Bortkiewicz, Paweł. Promocja wartości pracy ludzkiej Kardynała Stefana Wyszyńskiego. Lublin: Praca doktorska, arch. KUL, 1989.

Czaczkowska, Ewa K. Kardynał Wyszyński. Biografia. Kraków: Wydawnictwo Znak, 2013.

Dzieci moje. Biskup Stefan Wyszyński Ordynariusz Lubelski 1946-1949. Pamiętnik wystawy zorganizowanej przez Fundację na rzecz Rodziny Nasza Tradycja w 70.rocznicę ingresu do Katedry Lubelskiej Biskupa Stefana Wyszyńskiego, red. Piotr K. Kuty. Lublin: Nasza Tradycja 2017.

Jan Paweł II. „Wychowanie jest pierwszym i zasadniczym zadaniem kultury”. Przemówienie w siedzibie Organizacji Narodów Zjednoczonych do spraw Oświaty, Nauki i Kultury [UNESCO], Paryż, 2 czerwca 1980. W: Wychowanie w nauczaniu Jana Pawła II (1978-1999). Warszawa: WSZiP, 2000.

Kadziński, Roman. „Wskazania Prymasa Tysiąclecia dla »Solidarności«”. Słowo Powszechne 147 (1986). Kędziora, Bogdan. „Zawalczmy o młode pokolenie”. Niedziela 5/31 (2021): 49.

Micewski, Andrzej. Kardynat Wyszyński, prymas i mąż stanu. Paryż: Éditions du dialogue, 1982.

Miziołek, Władysław. „Osobowość, życie i działalność Stefana Kardynała Wyszyńskiego Prymasa Polski”. W: Stuga Boży Stefan kardynał Wyszyński (1901-1981). Co Kościół i Polska zawdzięczaja Prymasowi Tysiąclecia?, red. Stanisław Budzyński, Irena Burchacka, Adam Mazurek, 15-38. Warszawa: Oficyna Wydawniczo-Poligraficzna „Adam”, 2000.

Nitecki, Piotr. „Z Włocławka do Lublina. Nominacja, konsekracja oraz ingres biskupa Stefana Wyszyńskiego". Studia Włocławskie 11 (2009): 412-413.

Pylak, Bohdan. Stefan Wyszyński Biskup Lubelski 1946-1949. Lublin: Redakcja Wydawnictw KUL, 2000. 
Prymas Wyszyński a niepodległa. Naród - Patriotyzm - Państwo w nauczaniu Prymasa Tysiąclecia, red. Ewa K. Czaczkowska, R. Łatka. Warszawa: WN UKSW, 2019.

Raina, Peter. Stefan kardynał Wyszyński Prymas Polski, t. 1. Londyn: Oficyna Poetów i Malarzy, 1979. Romaniuk, Marian P. Prymas Tysiąclecia w słowie pisanym. Bibliografia życia, twórczości i postugi Kardynała Stefana Wyszyńskiego 1921-2017. Warszawa: WN UKSW, 2018.

Romaniuk, Marian P. Życie, twórczość i posługa Stefana Kardynała Wyszyńskiego Prymasa Tysiąclecia, t. 1. Warszawa: Instytut Wydawniczy PAX, 1994.

Rynio, Alina. „Ponadczasowa wartość i atrakcyjność pedagogicznego przesłania czcigodnego Sługi Bożego kardynała Stefana Wyszyńskiego". W: Rodzina - Wychowanie - Przyszłość, red. Elżbieta Osewska, Józef Stala, 334-362. Kraków: WN UPJPII w Krakowie, 2020.

Rynio, Alina. „Cele wychowania młodzieży w nauczaniu Prymasa Tysiąclecia. Analiza pedagogiczna w świetle Prawa i Przyrzeczenia Harcerskiego". W: Wychowanie chrześcijańskie metodą harcerska, red. Anna Petkowicz, 211-223. Lublin: Wydawnictwo KUL, 2009.

Rynio, Alina. Idea narodu i odpowiedzialności za naród w kazaniach milenijnych Czcigodnego Sługi Bożego Kardynała Stefana Wyszyńskiego. Lublin: Wydawnictwo KUL, 2020.

Rynio, Alina. „Mądre wychowanie patriotyczne przedmiotem troski Prymasa Tysiąclecia”. Studia Prymasowskie UKSW 4 (2011): 247-264.

Rynio, Alina. „Myśl pedagogiczna Stefana Kardynała Wyszyńskiego”. W: Myśl społeczna, red. Stanisław Fel, Marek Wódka, 47-70. Lublin: Wydawnictwo KUL, 2017.

Rynio, Alina. „Rodzina jako Kościół domowy w nauczaniu Kard. Stefana Wyszyńskiego”. W: Rodzina jako Kościół domowy, red. Antoni Tomkiewicz, Włodzimierz Wieczorek, 115-131. Lublin: Wydawnictwo KUL, 2010.

Rynio, Alina. „Społeczne wychowanie młodzieży w nauczaniu Prymasa Tysiąclecia jako warunek przetrwania narodu i kultury". W: O społeczeństwie wychowaniu i pracy w myśli Kardynała Stefana Wyszyńskiego, red. Lidia Marszałek, Adam Solak, 79-100. Warszawa: WN UKSW, 2010.

Rynio, Alina. Wychowanie młodzieży w nauczaniu Kardynała Stefana Wyszyńskiego. Lublin: Redakcja Wydawnictw KUL, wyd. 1, 1995; Lublin: Wydawnictwo KUL, wyd. 2, 2001.

Rynio, Alina. „Wychowawcza wartość biografii Kardynała Stefana Wyszyńskiego”. Ateneum Kapłańskie 3 (2018): 469-486.

Stefan Wyszyński. Chrześcijańska doktryna społeczna, red. Marek Wódka, Stanisław Fel. Lublin: Wydawnictwo KUL, 2020.

Śladami Księdza Stefana Wyszyńskiego, Lubelszczyzna - Zamojszczyzna - Ziemia Chełmska, red. Andrzej Kulik. Lublin: Koło Przyjaciół Prymasa Tysiąclecia przy parafii pw. Św. Urszuli Ledóchowskiej w Lublinie, 2016.

Zieliński, Zygmunt. „Życie w służbie Boga i ojczyzny. Życiorys Księdza Prymasa Stefana Wyszyńskiego". Chrześcijanin w Świecie 8/44 (1976): 2-20. 